Research letter

\title{
Morphometric variability of mandible linear characteristics depending on level of teeth alveolus position
}

\author{
Olga Yu. Aleshkina, Elena V. Chernyshkova, Dmitry N. Rossoshansky, Tatiana S. Bikbaeva, Irina A. Polkovova
}

Saratov State Medical University n.a. V.I. Razumovsky, Saratov, Russia

Received 23 November 2016, Revised 8 February 2017, Accepted 5 March 2017

(C) 2016, Aleshkina O.Yu., Chernyshkova E.V., Rossoshansky D.N., Bikbaeva T.S., Polkovova I.A.

(C) 2016, Russian Open Medical Journal

\begin{abstract}
The goal was to define morphometric variability of altitude and thickness parameters of alveolar part of a mandible depending on level of teeth alveolus position.

Material and Methods - The study was carried out using 70 passported skulls with mandibles of adults aged 21-60 years and 30 isolated mandibles excluding sex and age from scientific craniological collection of fundamental museum of human anatomy department of Saratov State Medical University n.a. V.I. Razumovsky (Saratov, Russia). Craniometrical method was used to study parameters of both sides of a mandible: altitude - from base of mandible to level of apex of medial incisors, canine, $1^{\text {st }}$ and $2^{\text {nd }}$ premolars, $1^{\text {st }}, 2^{\text {nd }}$ and $3^{\text {rd }}$ molars; thickness - in vestibular-lingual direction at the same levels.

Results and Conclusion - The highest altitude was marked at levels of incisors and $3^{\text {rd }}$ molar, the smallest one - at level of $1^{\text {st }}$ and $2^{\text {nd }}$ molars; maximum mandible thickness was defined at level of $2^{\text {nd }}$ molar, minimum - at levels of canine and $1^{\text {st }}-2^{\text {nd }}$ premolars on both sides of mandible; average thickness was revealed at levels of incisors, $1^{\text {st }}$ and $2^{\text {nd }}$ molars and had the same statistical values. Bilateral variability of thickness was significantly dominating on the right side and only at levels of $1^{\text {st }}-2^{\text {nd }}$ premolars and $1^{\text {st }}$ molar. Average values of altitude and thickness from both sides of mandible and at all levels had medium degree of variability.
\end{abstract}

Keywords: mandible, variability, mandible altitude, mandible thickness, teeth alveolus

Cite as Aleshkina OYu, Chernyshkova EV, Rossoshansky DN, Bikbaeva TS, Polkovova IA. Morphometric variability of mandible linear characteristics depending on level of teeth alveolus position. Russian Open Medical Journal 2017; 6: e0202.

Correspondence to Prof. Olga Yu. Aleshkina. Address: Human Anatomy Department, Saratov State Medical University n.a. V.I. Razumovsky, 112, B. Kazachya str., Saratov, 410012, Russia. Phone: +7 (8452) 66-97-65. E-mail: aleshkina_ou@mail.ru

\section{Introduction}

Preservation of anatomical integrity and functioning of mandible as well as restoration of its bone structures damaged due to pathological processes, injuries and operations, requiring surgical and further prosthetic treatment have been considered as important problems in maxillofacial surgery up to the present time $[1,2]$. Thus, anatomical features of mandible structure have been in the focus of clinically based studies for planning and carrying out orthopedic treatment, in particular - intraosseous dental implantation [3-5]. Development of procedures for selecting area and consistent pattern of placing implant in mandible in various clinical situations has been associated with individual anatomical peculiarity of its alveolar part.

Along with advances in studying forms and spatial organization of skull structures [6], there have been put new requirements to knowledge of size, shapes, age and sex variability of mandible and their relationship with skull as a whole $[7,8]$. There is no enough data on alveolar part of mandible in literature, most of the facts have fragmented or partial character $[9,10]$. While morphometric characteristics of alveolar part and its relationship with other structures of mandible are used in computer modeling of mandible and virtual dental implants for further selection of implants placement area, treatment planning and management $[11,12]$. Thereby, information about anatomical variability of mandible alveolar part is considered to be the necessary anatomical basis for clinical dentistry and still remains relevant.

The goal was to define morphometric variability of altitude and thickness parameters of alveolar part of a mandible depending on level of teeth alveolus position.

\section{Material and Methods}

The study was carried out using 70 passported skulls with mandibles of adults aged 21-60 years and 30 isolated mandibles excluding sex and age, without mechanic injuries and systemic disorders of skeleton from scientific craniological collection of fundamental museum of human anatomy department of Saratov State Medical University n.a. V.I. Razumovsky (Saratov, Russia). Craniometrical method by means of technical calipers with scale division of $0.01 \mathrm{~mm}$, according to common method in craniology, the present study of parameters of both sides of a mandible was carried out: altitude - from base of mandible to level of apex of medial incisors, canine, $1^{\text {st }}$ and $2^{\text {nd }}$ premolars, $1^{\text {st }}, 2^{\text {nd }}$ and $3^{\text {rd }}$ molars; thickness - in vestibular-lingual direction at the same levels. 
Table 1. Variability of altitude of mandible depending on level of teeth alveolus position

\begin{tabular}{|c|c|c|c|c|c|c|c|}
\hline \multirow{2}{*}{ Levels of measuring } & & \multicolumn{6}{|c|}{ Variation and statistic parameters } \\
\hline & & Min-Max & $\mathrm{M} \pm \mathrm{m}$ & $\sigma$ & $C V, \%$ & $\mathrm{P} 1$ & $\mathrm{P} 2$ \\
\hline Medial incisors & & $1.5-3.7$ & $2.9 \pm 0.04$ & 0.4 & 15.0 & & \\
\hline \multirow{2}{*}{ Canine } & $\mathrm{R}$ & $1.3-3.6$ & $2.8 \pm 0.05$ & 0.4 & 16.0 & \multirow{2}{*}{$>0.05$} & $>0.05$ \\
\hline & $\mathrm{L}$ & $1.0-3.5$ & $2.7 \pm 0.05$ & 0.5 & 19.0 & & $>0.05$ \\
\hline \multirow{2}{*}{$1^{\text {st }}, 2^{\text {nd }}$ premolars } & $\mathrm{R}$ & $1.0-3.5$ & $2.7 \pm 0.05$ & 0.5 & 19.0 & \multirow{2}{*}{$>0.05$} & $<0.001$ \\
\hline & $\mathrm{L}$ & $1.0-3.5$ & $2.7 \pm 0.05$ & 0.5 & 19.0 & & $<0.001$ \\
\hline \multirow{2}{*}{$1^{\text {st }}$ molar } & $\mathrm{R}$ & $1.1-3.2$ & $2.4 \pm 0.04$ & 0.4 & 17.0 & \multirow{2}{*}{$>0.05$} & $>0.05$ \\
\hline & $\mathrm{L}$ & $1-3.2 .0$ & $2.4 \pm 0.04$ & 0.4 & 18.0 & & $>0.05$ \\
\hline \multirow{2}{*}{$2^{\text {nd }}$ molar } & $\mathrm{R}$ & $1.9-3.1$ & $2.5 \pm 0.10$ & 0.3 & 13.0 & \multirow{2}{*}{$>0.05$} & $>0.05$ \\
\hline & $\mathrm{L}$ & $1.1-3.1$ & $2.4 \pm 0.10$ & 0.5 & 22.0 & & $>0.05$ \\
\hline \multirow{2}{*}{$3^{\text {rd }}$ molar } & $\mathrm{R}$ & $2.5-3.3$ & $2.9 \pm 0.10$ & 0.3 & 10.0 & \multirow{2}{*}{$>0.05$} & $<0.001$ \\
\hline & $\mathrm{L}$ & $2.2-3.3$ & $2.8 \pm 0.10$ & 0.3 & 13.0 & & $<0.001$ \\
\hline
\end{tabular}

$\mathrm{R}$, right; L, left; $\mathrm{P} 1$, reliability between sides of a parameter; $\mathrm{P} 2$, reliability between levels of measuring.

Table 2. Variability of thickness of mandible depending on level of teeth alveolus position

\begin{tabular}{|c|c|c|c|c|c|c|c|}
\hline \multirow{2}{*}{ Levels of measuring } & & \multicolumn{6}{|c|}{ Variation and statistic parameters } \\
\hline & & Min-Max & $\mathrm{M} \pm \mathrm{m}$ & $\sigma$ & $C V, \%$ & P1 & $\mathrm{P} 2$ \\
\hline \multicolumn{2}{|l|}{ Medial incisors } & $1.0-2.0$ & $1.4 \pm 0.02$ & 0.2 & 14.0 & \multirow{3}{*}{$>0.05$} & \multirow{3}{*}{$\begin{array}{l}<0.05 \\
<0.05\end{array}$} \\
\hline \multirow{2}{*}{ Canine } & $\mathrm{R}$ & $0.9-1.9$ & $1.3 \pm 0.02$ & 0.2 & 15.0 & & \\
\hline & $L$ & $0.9-1.8$ & $1.3 \pm 0.02$ & 0.1 & 14.0 & & \\
\hline \multirow{2}{*}{$1^{\text {st }}, 2^{\text {nd }}$ premolars } & $\mathrm{R}$ & $0.7-2.0$ & $1.3 \pm 0.03$ & 0.2 & 21.0 & \multirow{2}{*}{$<0.05$} & \multirow{2}{*}{$\begin{array}{l}>0.05 \\
<0.05\end{array}$} \\
\hline & $L$ & 0.7-1.9 & $1.2 \pm 0.02$ & 0.1 & 19.0 & & \\
\hline \multirow{2}{*}{$1^{\text {st }}$ molar } & $\mathrm{R}$ & $0.8-2.0$ & $1.5 \pm 0.02$ & 0.2 & 17.0 & \multirow{2}{*}{$<0.01$} & \multirow{2}{*}{$\begin{array}{l}<0.001 \\
<0.001\end{array}$} \\
\hline & $L$ & $0.8-2.0$ & $1.4 \pm 0.02$ & 0.1 & 17.0 & & \\
\hline \multirow{2}{*}{$2^{\text {nd }}$ molar } & $\mathrm{R}$ & $1.2-1.9$ & $1.6 \pm 0.10$ & 0.2 & 13.0 & \multirow{2}{*}{$>0.05$} & \multirow{2}{*}{$\begin{array}{l}<0.01 \\
<0.001\end{array}$} \\
\hline & $L$ & $1.1-2.0$ & $1.6 \pm 0.10$ & 0.1 & 16.0 & & \\
\hline \multirow{2}{*}{$3^{\text {rd }}$ molar } & $\mathrm{R}$ & $1.1-1.7$ & $1.4 \pm 0.10$ & 0.2 & 14.0 & \multirow{2}{*}{$>0.05$} & \multirow{2}{*}{$\begin{array}{l}<0.001 \\
<0.001\end{array}$} \\
\hline & $\mathrm{L}$ & $1.2-1.9$ & $1.4 \pm 0.10$ & 0.1 & 15.0 & & \\
\hline
\end{tabular}

$R$, right; L, left; $P 1$, reliability between sides of a parameter; $P 2$, reliability between levels of measuring.

Statistic processing of the received data was fulfilled using the applied program «Statistica 6.0» for Windows. The following variation and static elements were determined for all craniometric parameters: mean $(\mathrm{M})$, standard error of mean $(\mathrm{m})$, standard deviation $(\sigma)$, coefficient of variation (CV, \%), minimum (Min), maximum (Max). Due to insignificant differences in variants from normal ones, reliability determination $(P)$ of average values was carried out by means of Student's t-criterion. Differences were considered statistically reliable at $\mathrm{P}<0.05$.

\section{Results}

It was revealed that altitude of mandible body between medial incisors was at average $2.9 \pm 0.04 \mathrm{~mm}(\mathrm{M} \pm \mathrm{m})$ (Table 1). Altitude at level of canines $(2.7 \pm 0.05 \mathrm{~mm}$ ) was lower at $0.2 \mathrm{~mm}$ than altitude between incisors and it corresponded to interval between $1^{\text {st }}$ and $2^{\text {nd }}$ premolars. Altitude at level of $1^{\text {st }}$ and $2^{\text {nd }}$ molars $(2.4 \pm 0.1 \mathrm{~mm}$ each; $P>0.05$ ) had equal value on both sides of mandible and at 0.5 $\mathrm{mm}$ lower than at levels of incisors; at $0.2 \mathrm{~mm}$ lower than at level of canines and premolars, that was statistically reliable $(P<0.001)$. Altitude of mandible body al level of $3^{\text {rd }}$ molar was more at $0.1 \mathrm{~mm}$ on the right side $(2.9 \pm 0.1 \mathrm{~mm})$ than on the left one. But this difference had no statistical reliability $(P>0.05)$ and corresponded to average value of incisors' level, and at $0.4 \mathrm{~mm}$ more than level of $1^{\text {st }}$ and $2^{\text {nd }}$ molars $(2.4 \pm 0.1 \mathrm{~mm} ; \mathrm{P}<0.001)$; at $0.2 \mathrm{~mm}$ - than premolars $(2.7 \pm 0.05 \mathrm{~mm})$. Altitude of mandible was higher at 0.1 $\mathrm{mm}$ on the right side at level of canine, on the left side $-3^{\text {rd }}$ molar and $2^{\text {nd }}$ molar as compared with opposite side of mandible, but these values had no reliable differences $(P>0.05)$.

Average values of mandible altitude at its different levels and sides had medial degree of variability (CV from $10 \%$ to $22 \%$ ): the highest was at level of $2^{\text {nd }}$ molar on the left side, the lowest - at $3^{\text {rd }}$ molar on the right side.

Thickness of mandible body at level of incisors on an average was $1.4 \pm 0.02 \mathrm{~mm}(\mathrm{M} \pm \mathrm{m})$ and increased at $0.1 \mathrm{~mm}(1.3 \pm 0.02 \mathrm{~mm})$ at level of canines and premolars (Table 2). Thickness of body between $1^{\text {st }}$ and $2^{\text {nd }}$ premolars $(1.3 \pm 0.03 \mathrm{~mm})$ and $1^{\text {st }}$ molar $(1.5 \pm 0.02 \mathrm{~mm})$ was at $0.1 \mathrm{~mm}$ more on the right side than on the left one in accordance to given levels $(1.2 \pm 0.02 \mathrm{~mm}$ and $1.4 \pm 0.02$ $\mathrm{mm}, \mathrm{P}<0.05$ and $\mathrm{P}<0.01)$.

Thickness of mandible increased at $0.2 \mathrm{~mm}$ at level of $1^{\text {st }}$ molar $\left(1.5 \pm 0.02 \mathrm{~mm} ; \mathrm{M} \pm \mathrm{m}\right.$ and at $0.3 \mathrm{~mm}-$ of $2^{\text {nd }} \operatorname{molar}(1.6 \pm 0.02 \mathrm{~mm})$, as compared with thickness at level of front teeth, reaching for its maximum value. At level of $3^{\text {rd }}$ molar $(1.4 \pm 0.10)$ mandible thickness decreased again at $0.2 \mathrm{~mm}$ and corresponded to thickness of incisors' level.

Thickness of mandible body at level of $1^{\text {st }}$ molar $(1.5 \pm 0.02 \mathrm{~mm})$ on the right side was reliably more than at incisors' level at $0.1 \mathrm{~mm}$ $(1.4 \pm 0.02 \mathrm{MM})$ and was more variable $(\mathrm{CV}=17 \% ; 14 \%)$, but on the left side this index had no statistically significant differences ( $P>0.05)$.

Thickness at level of premolars on the left side $(1.2 \pm 0.02 \mathrm{~mm})$ was reliably thinner at $0.1 \mathrm{~mm}$ than at level of canine 
$(1.3 \pm 0.02 \mathrm{~mm})$ of the same side of mandible, but it was more variable ( $C V=19 \%$; $14 \%)$, however on the right side this index had no statistically significant differences $(P>0.05)$, but thickness was more variable at level of premolars in comparison with canine's level ( $C V=21 \%$; 15\%).

Average values of thickness parameters of mandible at its different levels and on both of its sides had medial degree of variability (CV from 13\% to 21\%): maximal was at level of $1^{\text {st }}$ and $2^{\text {nd }}$ premolars on the right side, minimal was at level of $2^{\text {nd }}$ molar on the right side. The most variable thickness on both of the sides was at levels of $1^{\text {st }}, 2^{\text {nd }}$ premolars $(C V=21 \% ; 19 \%)$ in comparison with variability of thickness parameters at other levels of mandible.

\section{Discussion}

We defined variability of altitude and thickness parameters of mandible depending on level of teeth alveolus position. It was revealed that altitude on both of the sides of mandible was decreased at $0.5 \mathrm{~mm}$ beginning from incisors to $1^{\text {st }}$ and $2^{\text {nd }}$ molars, reaching for its minimal value, and increased again at $0.4 \mathrm{~mm}$ at levels of $3^{\text {rd }}$ molar corresponding to altitude of mandible body between medial incisors. The received data did not correspond to research data of L. Kudryavtseva and L. Lyakisheva [13], who have determined maximal altitude of mandible only at level of incisors, and minimal - at level of $3^{\text {rd }}$ tricuspid. Thickness of mandible's alveolar part was decreased at 0.1-0.2 $\mathrm{mm}$ beginning from medial incisors to level of canine and $1^{\text {st }}-2^{\text {nd }}$ premolars, it increased at $0.2 \mathrm{~mm}$ at level of $1^{\text {st }}$ molar and at 0.3-0.4 mm - of $2^{\text {nd }}$ molar in comparison with premolars; this fact was approved by the authors who revealed maximal thickness of mandible body at level of tricuspids and minimal - at level of premolars [13]. This variability of mandible parameters can be explained by differences in in structure and functions of various teeth groups. While due to atrophy of teeth alveolus, transverse dimension of upper edge of mandible's alveolar part is decreasing at $1-2 \mathrm{~mm}$ at all levels, except incisors area, altitude decreases at $2.5-6.0 \mathrm{~mm}$ at various parts of mandible [10]; this fact is caused by decreasing of chewing load at these sites $[10,14]$. Value variability of morphometric parameters of mandible's alveolar part should be taken into consideration in the process of choosing a diameter of entering implants and calculations of limit loads on intraosseous support for perception of chewing pressure [5].

\section{Conclusion}

Thus, maximal altitude was at level of incisors and $3^{\text {rd }}$ molar, minimal - at level of $1^{\text {st }}$ and $2^{\text {nd }}$ molar; maximal thickness on both sides of mandible was at level of $2^{\text {nd }}$ molar, minimal - at level of canine and $1^{\text {st }}-2^{\text {nd }}$ premolars; average value of thickness was at level of incisors, $1^{\text {st }}$ and $3^{\text {rd }}$ molars and had the same statistical values. Bilateral variability of thickness was relevantly prevailing on the right side at level of $1^{\text {st }}, 2^{\text {nd }}$ premolars and $1^{\text {st }}$ molar. Average values of altitude and thickness on mandible's both sides at all levels had medial degree of variability.

\section{Conflict of interest: none declared.}

\section{References}

1. Korlyakov DV, Deryabin El. Restoration of alveolar outgrowth after teeth extraction. Proceedings of conference of Bashkortostan dentists
"New technologies in dentistry" and 6-th International Specialized Exhibition "Stomatology of Ural-2005". Ufa, Russia, 2005: 153-155. Russian

2. Quereshy FA, Savell TA, Palomo JM. Applications of cone beam computed tomography in the practice of oral and maxillofacial surgery. J Oral Maxillofac Surg 2008; 66(4): 791-796. https://doi.org/10.1016/i.joms.2007.11.018.

3. Lyasnikov VN, Lepilin AV. Intraosseous dental implants. Structures, technologies, production and use in clinical practice. Saratov, Russia, 2002; 115 p. Russian

4. Paraskevich VL. Dental implantology. Minsk, Belarus: Unipress, 2002; 368 p. Russian

5. Robustova TG. Dental implantation (surgical aspects). Moscow, Russia: Medicine, 2003; 560 p. Russian

6. Aleshkina OYu. Basicranial topology of the human skull construction. Volgograd, Russia, 2007; 32 p. Russian

7. Gladilin YuA. Morphology of the human mandible. Saratov, Russia, 2013; 198 p. Russian

8. Kalmin OV, Malaniin IV, Zuylkina LA, Ivanov PV. Sex di fference in cranio facial and odontometrical characteristics of Penza and Penza region in habitants. Kubanskii Nauchnyi Meditsinskii Vestnik 2010; (1): 43-47. Russian

9. Aleshkina OYu, Rossoshansky DN, Polkovova IA, Bikbaeva TS Morphometrical variability of dental alveoli of mandible in adults. Saratov Journal of Medical Scientific Research 2016; 12(2): 110-112. Russian

10. Nesterov AA. Anatomy of mandible and dental implantation problems. Actual issues of clinical anatomy and operative surgery. SaintPetersburg, Russia, 2003; 160 p. Russian

11. Ramasamy M, Giri, Raja R, Subramonian, Karthik, Narendrakumar R. Implant surgical guides: From the past to the present. J Pharm Bioall Sci 2013; 5, Suppl S1: 98-102. https://doi.org/10.4103/09757406.113306.

12. Hassan B, van der Stelt P, Sanderink G. Accuracy of three-dimensional measurements obtained from cone beam computed tomography surface-rendered images for cephalometric analysis: influence of patient scanning position. Eur J Orthod 2009; 31(2): 129-134. https://doi.org/10.1093/ejo/cjn088.

13. Kudryavtseva LE, Lyakisheva LA. About anatomy of teeth-jaw segments of upper jaw and mandible. Archive of Anatomy, Histology and Embryology 1973; (5): 88-93. Russian

14. Gaivoronskaya MG, Komarnitsky OV. Basic morphometric parameters of alveolar part of intact mandible. Saint-Petersburg, Russia, 2010: 33 37. Russian

\section{Authors:}

Olga Yu. Aleshkina - MD, D.Sc., Professor, Head of Human Anatomy Department, Saratov State Medical University n.a. V.I. Razumovsky, Saratov, Russia. https://orcid.org/0000-0003-2151-1208

Elena V. Chernyshkova - D.Sc., Assistant Professor, Head of Foreign Languages Department, Saratov State Medical University n.a. V.I. Razumovsky, Saratov, Russia. http://orcid.org/0000-0002-1027-7738

Dmitry N. Rossoshansky - Postgraduate, Human Anatomy Department, Saratov State Medical University n.a. V.I. Razumovsky, Saratov, Russia. https://orcid.org/0000-0002-3569-8678

Tatiana S. Bikbaeva - MD, PhD, Assistant, Human Anatomy Department, Saratov State Medical University n.a. V.I. Razumovsky, Saratov, Russia. http://orcid.org/0000-0002-7779-0317

Irina A. Polkovova - MD, PhD, Assistant, Human Anatomy Department, Saratov State Medical University n.a. V.I. Razumovsky, Saratov, Russia. https://orcid.org/0000-0002-2985-7302 